\title{
Piotr Kosiorek
}

\section{Osadnictwo żydowskie w kontekście konfliktu izraelsko-palestyńskiego}

\begin{abstract}
Abstrakt
Osadnictwo żydowskie jest jednym z najważniejszych elementów wieloletnich sprzeczności między Izraelem i Palestyną. Ponadto problematyczny pozostaje tutaj status prawny osiedli. Wciąż trwa dyskusja nad tym, czy kolonie założone na Zachodnim Brzegu Jordanu są legalne, czy wręcz przeciwnie. Celem niniejszego tekstu będzie zbadanie znaczenia osadnictwa żydowskiego w kontekście konfliktu izraelsko-palestyńskiego oraz próba odpowiedzi na pytanie, jak wysoko w hierarchii priorytetów państwa sytuuje się osadnictwo żydowskie. W treści tego artykułu poruszane są takie kwestie jak mur bezpieczeństwa wraz z jego funkcjami i konsekwencjami dla Palestyńczyków, kwestia administracji Zachodniego Brzegu Jordanu oraz studium przypadku opisujące przykład Kfar Etzion i Sheikh Jarrah.
\end{abstract}

Słowa kluczowe: Izrael, Palestyna, konflikt izraelsko-palestyński, osadnictwo żydowskie, Zachodni Brzeg Jordanu

\section{Wstęp}

Relacje między Izraelem a Palestyną są naznaczone wieloma spornymi kwestiami, które utrudniają prowadzenie rozmów pokojowych oraz negocjacji. Obok najbardziej istotnych problemów wymagających rozwiązania łatwo doszukać się kolejnych zagadnień rzutujących na konfliktogenność stosunków między dwoma stronami. Obecnie można wskazać trzy elementy, bez których nie sposób mówić o osiągnięciu porozumienia. Pierwszym jest osadnictwo żydowskie na Zachodnim Brzegu Jordanu uznawane za nielegalne przez większość państw świata i organizacji międzynarodowych z ONZ włącznie ${ }^{1}$. Drugim jest

1 J. Jarząbek, Żydowskie osadnictwo na Zachodnim Brzegu Jordanu, „Wschodnioznawstwo” 2007, s. 427. 
tzw. „bariera bezpieczeństwa”, w postaci ograniczeń fizycznych (betonowe bloki, drut kolczasty), której budowa wzbudziła liczne dyskusje. Trzecim jest status Jerozolimy, która zarówno dla jednego, jak i drugiego narodu ma olbrzymie znaczenie tożsamościowe. Do wymienionych zagadnień należy dodać także problem uchodźców palestyńskich, a także niesprecyzowaną wizję spornego terytorium. W kwestii rozwiązania konfliktu izraelsko-palestyńskiego istnieją dwa przeciwstawne stanowiska proponujące różne rozwiązania dotyczące przyszłości państwa (państw) w Palestynie. Rozwiązanie dwupaństwowe (two-state solution) proponuje utworzenie dwóch niezależnych państw i rozdzielenie Palestyny od państwa żydowskiego. Natomiast rozwiązanie jednopaństwowe (one-state solution) przedstawiane obecnie w kilku wariantach optuje za połączeniem Izraela, Zachodniego Brzegu Jordanu oraz Strefy Gazy w jeden kraj. Jak widać, katalog punktów spornych jest dość obszerny, a dana kontrowersja może generować następne niezgodności. Niniejszy tekst będzie koncentrował się na pierwszej z wymienionych kwestii, która jest niewątpliwie czynnikiem utrudniającym relacje między Palestyną a Izraelem. Osadnictwo żydowskie jest jednym z najważniejszych elementów wieloletnich sprzeczności między dwoma stronami. Ponadto problematyczny pozostaje tutaj status prawny osiedli. Wciąż trwa dyskusja nad tym, czy kolonie założone na Zachodnim Brzegu Jordanu są legalne, czy wręcz przeciwnie. Osiedla są związane z wieloletnim procesem kolonizacji Palestyny, a ruch osadniczy był jednym $\mathrm{z}$ ważniejszych czynników mających wpływ na powstanie państwa Izrael w $1948 \mathrm{r}$. Wewnątrz niektórych zbiorowisk panowały wewnętrzne zasady, regulujące życie wspólnoty żydowskiej. Nie bez znaczenia pozostawały tutaj również idee stworzone przez kolonistów, które stawiały sobie za cel przede wszystkim edukację najmłodszych. Pierwsze kibuce odegrały istotną rolę nie tylko w kształtowaniu się małych, wewnętrznych i hermetycznych społeczności, lecz również w formowaniu się przyszłych elit politycznych państwa żydowskiego $^{2}$. Oprócz tego istniało także wiele osad typowo rolniczych. Celem niniejszego artykułu będzie zbadanie znaczenia osadnictwa żydowskiego w kontekście konfliktu izraelsko-palestyńskiego oraz próba odpowiedzi na pytanie, jak wysoko w hierarchii priorytetów państwa sytuuje się osadnictwo żydowskie. W analizie zostanie wykorzystana metoda systemowa, decyzyjna oraz instytucjonalno-prawna. W znacznym stopniu pomogą one udzielić odpowiedzi na pytanie, czy osadnictwo żydowskie wpisuje się w kreowanie polityki wewnętrznej tego państwa.

2 Kibuc, https://encyklopedia.pwn.pl/haslo/kibuc;3921998.html (16 II 2019). 


\section{Determinanty relacji władz Izraela z Palestyńczykami}

W celu zbadania kwestii osadnictwa żydowskiego w świetle konfliktu izraelsko-palestyńskiego należy wskazać na pewne okoliczności wpływające na kreowanie tejże polityki oraz specyfikę podejścia państwa żydowskiego oraz jego decydentów w stosunku do Palestyńczyków. Są to takie kwestie jak status i sytuacja polityczna w Autonomii Palestyńskiej (1), starania strony palestyńskiej o uznanie na arenie międzynarodowej wraz z ewolucją relacji z władzami Izraela w związku z rozpadem dwubiegunowego świata (2) oraz podejście decydentów polityki państwa żydowskiego do kwestii spornych i newralgicznych dotyczących konfliktu izraelsko-palestyńskiego w świetle aktów mowy i oficjalnych wypowiedzi/ stanowisk (3).

1) Pierwszą kwestią jest status i sytuacja polityczna w Autonomii Palestyńskiej. W sensie formalnym Palestyna nie jest państwem, lecz strukturą administracyjną zarządzającą (częściowo) obszarem Zachodniego Brzegu Jordanu oraz Strefą Gazy. Sytuacja polityczna w Autonomii Palestyńskiej jest o tyle trudna, iż wewnątrz struktury nie ma jednego scentralizowanego ośrodka władzy. Właściwie można mówić o 3 aktorach mających wpływ na realizację i kreowanie jej polityki. Jest to przede wszystkim Organizacja Wyzwolenia Palestyny (OWP) uznawana przez społeczność międzynarodową oraz oficjalnie reprezentującą Palestynę, zarówno w relacjach z Izraelem, jak i na arenie międzynarodowej, administracja Fatahu (Palestyński Ruch Wyzwolenia Narodowego), będącego palestyńską formacją polityczną, oficjalnie zarządzającą obszarem Zachodniego Brzegu oraz Hamas (Islamski Ruch Oporu), który sprawuje faktyczną kontrolę nad Strefą $\mathrm{Gazy}^{3}$. Obecnie Autonomia Palestyńska zmaga się z problemem dwuwładzy. Z jednej strony jest to partia Fatah utrzymująca przewodnią pozycję w OWP, z drugiej strony jest to Hamas zarządzający Strefą Gazy. Obydwa ugrupowania mają inną wizję utworzenia państwa palestyńskiego i z tego względu są ze sobą skonfliktowane. Państwo arabskie w Palestynie miało powstać w roku 1948, jednak wojna o niepodległość Izraela przekreśliła ten plan. W wyniku konfliktu, część terenów przyznanych państwu arabskiemu na mocy rezolucji ONZ nr 181 zajął powstający Izrael. Po wojnie o niepodległość inne terytoria zostały zajęte przez Transjordanię i Egipt, które nie chciały zrzec się zdobytych ziem na rzecz utworzenia państwa palestyńskiego. Po wojnie sześciodniowej w 1967 r. Izrael zajął Zachodni Brzeg Jordanu, Półwysep Synaj, Wschodnią Jerozolimę, Strefę Gazy oraz

M. Szydzisz, Polityka zagraniczna Palestyny, [w:] Wprowadzenie do polityki zagranicznej muzułmańskich państw Bliskiego Wschodu i Afryki Północnej, M. Woźniak-Bobińska, A.M. Solarz (red.), Warszawa 2018, s. 29. 
Wzgórza Golan ${ }^{4}$. Utrata tych ziem była pewnego rodzaju katalizatorem kształtowania palestyńskiego nacjonalizmu i palestyńskiej tożsamości oraz świadomości narodowej. Wybuch Intifady w $1987 \mathrm{r}$. nie pozostawił już wątpliwości co do tego, że tożsamość palestyńska istnieje, a Palestyńczyków należy uznać za w pełni ukształtowany naród ${ }^{5}$. W 1993 r. podpisano I porozumienie w Oslo (Deklaracja Zasad), rok później podpisano porozumienie Gaza-Jerycho (tzw. Porozumienie z Kairu), a w 1995 r. doszło do podpisania porozumienia Oslo II (Tymczasowe porozumienie o Zachodnim Brzegu i Strefie Gazy). Na mocy tych dokumentów utworzono tymczasową strukturę administracyjną zarządzającą Zachodnim Brzegiem Jordanu i Strefą Gazy oraz uznano pewną formę samorządności Palestyńczyków na tych obszarach. Stronami porozumienia były Organizacja Wyzwolenia Palestyny oraz Izrael. Hamas nie zaakceptował wówczas podpisania dokumentów uznając to za zdradę wobec sprawy palestyńskiej, a środowisko związane z Jasirem Arafatem oskarżył o kierowanie się własnymi, partykularnymi interesami za pośrednictwem ugody z okupantem ${ }^{6}$.

2) Drugie zagadnienie dotyczy dążeń polityków palestyńskich do uznania przez szeroko rozumianą społeczność międzynarodową. Ugrupowania palestyńskie na czele z OWP starały się w możliwie jak największym stopniu umiędzynarodowić kwestię palestyńskiej państwowości. Działania te przyniosły połowiczny sukces, w związku z upodmiotowieniem OWP przez ONZ w listopadzie 1974 r. na mocy rezolucji 3236. Jednak sytuacja Palestyńczyków zamieszkujących tereny zajęte przez Izrael w wyniku wojen wciąż nie ulegała żadnej zmianie. Państwo żydowskie nie chciało prowadzić żadnego dialogu z ludnością palestyńską. Dopiero zakończenie zimnej wojny oraz rozpad ZSRR wraz z końcem podziału na dwubiegunowy świat zmieniły tę sytuację?. Początek lat 90 . XX w. należy uznać za punkt zwrotny w relacjach między Izraelczykami a Palestyńczykami z uwagi na dojście do władzy izraelskiej lewicy. W tym czasie można było zaobserwować zmianę w dyskursie i nastawienie na dialog, co stanowi dużą zmianę w porównaniu do lat wcześniejszych. Mimo wymijających deklaracji i innych utrudnień zaczęto podejmować rozmowy o państwowości palestyńskiej.

4 W ramach projektu „ziemia za pokój” rząd izraelski zdecydował się wówczas zrezygnować z Półwyspu Synaj i Wzgórz Golan. Za: Idem, Religijne wymiary konfliktu izraelsko-palestyńskiego, „Wschodnioznawstwo” 2012, s. 168-169.

$5 \quad$ Idem, Sekurytyzacja jako narzędzie polityki zagranicznej Izraela w świetle teorii regionalnych kompleksów bezpieczeństwa, Warszawa 2019, s. 188-190.

6 J. Jarząbek, Palestyńczycy na drodze do niepodległości. Rozwój, przemiany i kryzys ruchu narodowego, Warszawa 2012, s. 106-108; A. Nüsse, Muslim Palestine: The ideology of Hamas, Amsterdam 1998, s. 145-148.

7 M. Szydzisz, Sekurytyzacja jako narzędzie..., s. 188-190. 
Jest to duża zmiana w kontekście przeszłości, dlatego czasy rządów izraelskiej lewicy (dokładnie Partii Pracy) w latach 90. XX w. należy uznać za punkt zwrotny. Rozpoczęcie procesu pokojowego również datuje się na ten okres, co potwierdza powyższe stwierdzenie. W kwestii umiędzynarodowienia sprawy palestyńskiej istotna jest zmiana sytuacji geopolitycznej i rozpad dwubiegunowego świata. Zakończenie zimnej wojny skutkowało tym, że sprawa palestyńska straciła swoich protektorów, którymi były kraje komunistyczne. Nowa sytuacja geopolityczna zmusiła stronę palestyńską do redefinicji oraz przemodelowania swojej polityki. To właśnie te zmiany doprowadziły do zapoczątkowania procesu pokojowego, utworzenia Autonomii Palestyńskiej oraz przekazania tej strukturze obszarów Zachodniego Brzegu oraz Strefy Gazy ${ }^{8}$.

3) Ostatnim elementem mającym wpływ na relacje Państwa Izrael i jego decydentów z Palestyńczykami jest podejście tych pierwszych do newralgicznych, kontrowersyjnych oraz wymagających rozwiązania kwestii dotyczących konfliktu. Wiadomym jest, że obecnie kontrowersji i nierozwiązanych kwestii jest wiele. Są to m.in. wspomniane we wstępie status Jerozolimy, mur bezpieczeństwa, kwestia uchodźców palestyńskich, a także osiedla żydowskie oraz ich status w świetle izraelskiego oraz międzynarodowego prawodawstwa. Kwestie sporne bardzo często pojawiają bądź pojawiały się $\mathrm{w}$ wypowiedziach izraelskich polityków na przestrzeni lat. Oficjalne stanowiska i wywiady dotyczą relacji z Palestyńczykami, bezpieczeństwa i przyszłości państwa palestyńskiego oraz warunków bądź wymogów kierowanych pod adresem strony palestyńskiej. Można zaobserwować, że w tych wypowiedziach bardzo często obecne są kwestie sporne, które są różnie przedstawiane przez izraelskie władze w zależności od interesów państwa i bieżącej sytuacji politycznej. Czasami są one łączone w całość i stanowią nierozerwalny element negocjacji, innym razem każda kontrowersja stanowi oddzielny element składowy konfliktu. Kwestie sporne albo są włączane w katalog rozważań albo stanowią osobny kierunek dyskursu. Narracja zależy od bieżącej sytuacji politycznej, społecznej, gospodarczej bądź międzynarodowej Państwa Izrael. W kontekście wizji przyszłości państwa palestyńskiego jedną z wyróżniających się kwestii, obok statusu Jerozolimy oraz uchodźców palestyńskich jest właśnie osadnictwo żydowskie na Zachodnim Brzegu Jordanu i jego status w świetle prawa, zarówno izraelskiego, jak i międzynarodowego. Ten element jest bardzo często widoczny $\mathrm{w}$ dyskursie oraz uwypuklany przez izraelskie władze w kontekście relacji z Palestyną.

8 Idem, Polityka zagraniczna Palestyny..., s. 30-31. 


\section{Administracja Zachodniego Brzegu Jordanu}

Pomimo podpisania Deklaracji Zasad, tzw. porozumienia z Kairu (Gaza - Jerycho) oraz Tymczasowego porozumienia o Zachodnim Brzegu i Strefie Gazy (Oslo II) ostatecznie nie utworzono w pełni suwerennej palestyńskiej jednostki. Po śmierci premiera Rabina w 1995 r. jego następcą został Simon Peres, ale wybory w 1996 r. na stanowisko premiera Izraela wygrał Beniamin Netanyahu z partii Likud. Był on niechętny wobec rozmów z Palestyńczykami, dlatego szanse na osiągnięcie trwałego porozumienia znacznie się zmniejszyły 9 . Pomimo tego, za kadencji Beniamina Netanyahu 23 X 1998 r. zostało podpisane porozumienie, które przewidywało przekazanie dodatkowych $13 \%$ Zachodniego Brzegu Jordanu Autonomii Palestyńskiej (tzw. porozumienie z Wye River/Wye Plantation) $)^{10}$. Podział administracyjny tego obszaru jest kwestią nie do końca jasną i sprecyzowaną a uregulowania, które uzgodniono w porozumieniu Oslo II w 1995 r. komplikują zarządzanie tym terytorium stronie palestyńskiej. Pomimo tego, iż w opinii publicznej panuje przekonanie, że cały Zachodni Brzeg Jordanu znajduje się pod administracją Autonomii Palestyńskiej, w rzeczywistości jest jednak inaczej. Porozumienia z Oslo wprowadziły podział Zachodniego Brzegu na 3 strefy: A, B i C. W ramach tego podziału ustalono również w jaki sposób sprawowana będzie władza i kontrola nad tym obszarem. I tak oto postanowiono, że:

1) strefa A obejmująca $3 \%$ Zachodniego Brzegu znajdzie się pod kontrolą palestyńską;

2) strefa B obejmująca $24 \%$ będzie zarządzana przez administrację palestyńską, jednak w gestii Izraela będzie pilnowanie bezpieczeństwa;

3) strefa C obejmująca $73 \%$ będzie dystryktem, nad którym całkowitą władzę będzie miał Izrael ${ }^{11}$.

Podział na wymienione strefy, oprócz tego że jest skomplikowany, to rodzi nowe niejasności, które generują dalsze kontrowersje. Patrząc na mapę i analizując wydzielenie obszarów A, B i C widać, że „polityka planowania” Zachodniego Brzegu nie jest prowadzona wedle wyznaczników geograficznych. Podział Zachodniego Brzegu na 3 strefy dokonał się przez wzgląd na demografię. Na obszarach A i B rozsianych po całym Zachodnim Brzegu oraz będących mniejszą częścią tego terytorium przeważa ludność palestyńska. Strefa $\mathrm{C}$ będąca de facto otoczeniem stref A i B oraz znajdującą się pod całkowitą władzą państwa żydowskiego jest obszarem o największym potencjale rozwojowym ${ }^{12}$. Organizacja

Idem, Sekurytyzacja jako narzędzie..., s. 192-195.

10 M. Strużyński, Hamas wobec sporu palestyńsko-izraelskiego. Między procesem pokojowym a eskalacja konfliktu, „Historia i Polityka” 2013, nr 9, s. 89.

11 Ibidem.

12 B'Tselem (The Israeli Information Center for Human Rights in The Occupied Territories), Planning Policy in the West Bank, https://www.btselem.org/planning_and_building (20 IV 2021). 
B’Tselem podaje, iż polityka Państwa Izrael w tej strefie opiera się na założeniu, że rejon ten ma służyć przede wszystkim celom Izraela zarówno w sferze gospodarczej jak i politycznej ${ }^{13}$. Obszar ten obejmujący 73\% Zachodniego Brzegu jest miejscem, w którym bardzo dobrze prosperują niezgodne z prawodawstwem izraelskim osiedla żydowskie. Tak naprawdę rejon ten stanowi strefę wpływów państwa Izrael, które zabezpiecza w ten sposób swoje interesy. Według organizacji B’Tselem w tej sytuacji państwo żydowskie faktycznie zaanektowało strefę $\mathrm{C}^{14}$. Warto dodać, że wartości procentowe określające wartość terytorialną w określonych strefach różnią się w zależności od materiałów źródłowych. Sytuację określenia administracji Zachodniego Brzegu utrudnia również wspomniane porozumienie Wye Plantation/Wye River, w którym Izrael miał przekazać dodatkowych $13 \%$ ze strefy C pod administrację Autonomii Palestyńskiej. Jednak do tej pory przekazano jedynie $2 \%$ obszaru, ponieważ zrealizowano tylko początkowy etap porozumień ${ }^{15}$. Analizując podział administracyjny Zachodniego Brzegu Jordanu można wywnioskować, że Autonomia Palestyńska zarządza de facto niespełna $30 \%$ tego terytorium (strefy A i B). Warto pamiętać, że wciąż nie jest to pełna kontrola $\mathrm{z}$ uwagi na to, że w strefie B w gestii Państwa Izrael leży pilnowanie bezpieczeństwa. Wobec tego należy stwierdzić, że skonstruowany poprzez liczne porozumienia skomplikowany podział Zachodniego Brzegu ułatwia władzom Izraela nadużycia w stosunku do Palestyńczyków oraz nieprzestrzeganie prawa w kontekście m.in. „nieautoryzowanego” osadnictwa. Jest to duży paradoks, ponieważ nie tylko nie jest przestrzegane prawo międzynarodowe, ale również prawo Państwa Izrael, co wykazał opublikowany 8 III 2005 r. oficjalny izraelski raport rządowy, tzw. Raport Sasson ${ }^{16}$. Na fakt nieprzestrzegania umów międzynarodowych przez Izrael wskazuje także niedopełnienie postanowień zawartych w porozumieniu w Wye Plantation/Wye River. Problem ten odzwierciedla fakt, iż osadnictwo żydowskie nielegalne z punktu widzenia prawa Izraela jest włączane w politykę wewnętrzną tego państwa. Metody stosowane w celu osiągnięcia korzyści politycznych bądź ekonomicznych związane z zarządzaniem większością Zachodniego Brzegu nie uwzględniają ani zapisów porozumień, ani wymogów międzynarodowego i izraelskiego prawodawstwa.

\footnotetext{
13 Ibidem.

Ibidem.

15 J. Beinin, The Demise of the Oslo Process, https://web.archive.org/web/20000816222849/http:// www.merip.org/pins/pin1.html (20 IV 2020).

16 BBC News, Israel 'funded illegal outposts', http://news.bbc.co.uk/2/hi/middle_east/4328817.stm (20 IV 2021).
} 


\section{Izraelski mur bezpieczeństwa - funkcje konstrukcji i konsekwencje dla Palestyńczyków}

Elementem, który także wpisuje się w kwestie sporne i newralgiczne w kontekście konfliktu izraelsko-palestyńskiego jest mur bezpieczeństwa, który można uznać za podjęcie i zastosowanie środka nadzwyczajnego przez izraelskie władze. Decyzja o budowie konstrukcji zapadła 14 IV 2002 r., a inwestycję formalnie rozpoczęto $\mathrm{w}$ czerwcu tego roku ${ }^{17}$. Powodem, dla którego władze izraelskie zdecydowały się na budowę bariery były kwestie bezpieczeństwa. Głównymi argumentami za wzniesieniem muru było zabezpieczenie granic Izraela przed przemytem broni oraz materiałów wybuchowych, a także zapobieganie wkraczaniu potencjalnych zamachowców na terytorium kraju. Mur bezpieczeństwa jest zatem konstrukcją, która pełni funkcję prewencyjną, zabezpieczającą kraj przed terroryzmem. Inwestycja miała również przynieść korzyści dyplomatyczne, a także miała doprowadzić do osiągnięcia porozumienia między Izraelem i Palestyną ${ }^{18}$. Geograficznie bariera bezpieczeństwa miała oddzielać terytoria Autonomii Palestyńskiej od państwa żydowskiego oraz biec wzdłuż tzw. Zielonej Linii (granicy między Autonomią Palestyńską a Izraelem) i wewnątrz niej. Jednak w rzeczywistości mur powstaje w całości na Zachodnim Brzegu, widocznie „wcinając się” w głąb terytoriów palestyńskich ${ }^{19}$. Szacuje się, że skutkiem powstania bariery będzie włączenie ok. 8,5\% Zachodniego Brzegu Jordanu w granice Izraela, natomiast 3,4\% obszaru będzie w całości lub połowicznie okrążone przez mur ${ }^{20}$. Konstrukcja spełnia jeszcze jedną istotną funkcję w polityce wobec Zachodniego Brzegu Jordanu. Otacza nielegalne osiedla żydowskie oraz drogi dojazdowe do koloniii ${ }^{21}$. Jest to kolejne działanie podjęte przez Państwo Izrael, które nie uwzględnia interesów nieżydowskich członków społeczeństwa kraju, ponieważ przebieg muru znacznie utrudnia komunikację palestyńskiej ludności ${ }^{22}$. Bariera bezpieczeństwa de facto chroni osiedla żydowskie i pozwala na włączenie ich w oficjalne granice Izraela. Ten zabieg podjęty poprzez wprowadzenie środka nadzwyczajnego ma na celu utrwalenie izraelskiej obecności na Zachodnim Brzegu określanym w biblijnej nomenklaturze jako obszary Judei i Samarii. Wobec tego, obok celu prewencyjnego chroniącego państwo przed terroryzmem oraz przemytem istnieje jeszcze

17 B. Krzan, Izraelski mur bezpieczeństwa w świetle opinii doradczej Międzynarodowego Trybunału Sprawiedliwości [w:] Izrael i Autonomia Palestyńska, G. Tokarz, B. Albin (red.), Wrocław 2007, s. 225-228.

18 Ibidem.

19 J. Jarząbek, Palestyńczycy na drodze..., s. 225-227.

20 Ibidem.

21 J. Dyduch, Izraelskie wybory a konflikt z Palestyńczykami w latach 1992-2003, [w:] Izrael i Autonomia Palestyńska, G. Tokarz, B Albin (red.), Wrocław 2007, s. 68.

22 Ibidem. 
jeden, o którym władze Izraela nie wspominają w kontekście bariery bezpieczeństwa $^{23}$. Oficjalne stanowiska decydentów izraelskiej polityki oddzielają kwestię osadnictwa od muru bezpieczeństwa. Jednak można domniemać, że celem w wewnętrznej polityce bezpieczeństwa kraju poprzez budowę konstrukcji w głębi Zachodniego Brzegu była ochrona założonych niezgodnie z prawodawstwem osad. Powyższe stwierdzenie mogą potwierdzać liczby. Dane z 2007 r. (aktualizacja w 2012 r.) wykazywały, że w obrębie muru bezpieczeństwa, a dokładniej po jego zachodniej stronie (czyli obszarze okalającym biblijne terytoria Judei i Samarii) włączając w to Wschodnią Jerozolimę istniało ok. 60 osiedli, w których mieszkało ok. 380 tys. osadników ${ }^{24}$. Natomiast jeśli chodzi o bardziej aktualne dane, to izraelska organizacja Peace Now (Pokój Teraz) podaje, że na Zachodnim Brzegu znajdują się 132 osady i 113 placówek $^{25}$. Druga wartość odnosi się do kolonii zbudowanych bez oficjalnej autoryzacji. Pokój Teraz podaje również, że mieszka w nich więcej niż 413 tys. osadników oraz zaznacza, że ich liczba systematycznie rośnie z roku na rok (dane z listopada 2019 r.) ${ }^{26}$. Największe zagęszczenie osiedli można zaobserwować we Wschodniej Jerozolimie, gdzie istnieje 13 kolonii z 215 tys. mieszkańców ${ }^{27}$.

Budowa muru bezpieczeństwa jest krytykowana przez zachodnią opinię publiczną z uwagi na to, że wzbudziła wiele kontrowersji. Na ten fakt wskazuje nawet tak podstawowa kwestia jak nazewnictwo konstrukcji stosowanej przez jej przeciwników. Określają oni mur bezpieczeństwa jako „mur apartheidu” oraz porównują barierę do muru berlińskiego ${ }^{28}$. Podnoszone są również kwestie prawne związane z inwestycją. W świetle opinii doradczej Międzynarodowego Trybunału Sprawiedliwości (MTS) budowa muru narusza prawo do samostanowienia Palestyńczyków oraz wskazuje na niezgodność bariery z międzynarodowym prawem humanitarnym i ze standardem praw człowieka ${ }^{29}$. Oprócz tego MTS wskazał na fakt, iż przebieg konstrukcji został zaprojektowany w taki sposób, aby zamknąć w obszarze Zachodniego Brzegu jak największą liczbę osadników żydowskich mieszkających w nieautoryzowanych koloniach. MTS uznał, że Izrael prowadził

B. Krzan, op.cit.

J. Jarząbek, Palestyńczycy na drodze do niepodległości..., s. 225-227; B’Tselem (The Israeli Information Center for Human Rights in The Occupied Territories), The Separation Barrier Statistics, https://www.btselem.org/separation_barrier/statistics (24 IV 2021).

Organizacja Pokój Teraz dokonuje rozróżnienia pomiędzy osadami (settlements) a przyczółkami bądź placówkami (outposts). Można wywnioskować, że niezgodne z izraelskim i międzynarodowym prawodawstwem są te drugie.

Peace Now, Settlement watch, https://peacenow.org.il/en/category/settlement-watch (24 IV 2021); BBC News, Israel and the Palestinians: Can the settlement issue be solved?, https://www. bbc.com/news/world-middle-east-38458884 (24 IV 2021).

Ibidem.

B. Krzan, op.cit.

Ibidem, s. 231-234. 
zabiegi służące rozwijaniu nielegalnych z punktu widzenia prawa międzynarodowego i izraelskiego osiedli na Terytoriach Okupowanych co jest sprzeczne z art. 49 IV Konwencji Genewskiej ${ }^{30}$. Wobec powyższego, Międzynarodowy Trybunał Sprawiedliwości stwierdził, że „państwo okupacyjne nie posiada całkowitej swobody postępowania względem ludności i terytorium okupowanego" ${ }^{31}$. Ponadto MTS wykazuje obawy, że mimo deklaracji władz Izraela nie jest to jedynie konstrukcja tymczasowa, a mur jest działaniem służącym aneksji terytoriów palestyńskich. Oprócz Konwencji Genewskiej MTS podaje również nieprawidłowości związane z Konwencją Haską, której art. 46 i 52 wskazują, że istnienie muru jest pogwałceniem tej umowy międzynarodowej ${ }^{32}$.

Konfiskata i degradacja prywatnych gruntów palestyńskich związana z budową bariery bezpieczeństwa prowadzi do sytuacji, w której Palestyńczycy tracą możliwość zagospodarowania swojej ziemi i uprawiania swoich pól. W samym Bilin (jedna $\mathrm{z}$ wiosek położona na Zachodnim Brzegu Jordanu) mur bezpieczeństwa oddziela ludność palestyńską od połowy uprawianych pól, czyli około 200 hektarów ${ }^{33}$. Wobec powyższego, można stwierdzić, że budowa konstrukcji oraz jej konsekwencje dla Palestyńczyków nie idą w parze z międzynarodowym prawem humanitarnym oraz ze standardem praw człowieka.

\section{Osadnictwo żydowskie - stan obecny i studium przypadku}

Kfar Etzion jest osadą pełniącą rolę religijnego kibuca, leżącą na Wzgórzach Judzkich pomiędzy Jerozolimą a Hebronem. W wyniku wojny sześciodniowej stało się pierwszą izraelską osadą na okupowanym Zachodnim Brzegu Jordanu ${ }^{34}$. Wśród Żydów, którzy założyli kolonię byli potomkowie grupy osadników, którzy walczyli w 1948 roku o utrzymanie przyczółka. Powodem, który miał usankcjonować istnienie osady na Terytoriach Okupowanych był argument prawa powrotu do ziemi, z której przodkowie nowych mieszkańców zostali w przeszłości wygnani. Rząd Izraela rozpatrzył pozytywnie to uzasadnienie i pozwolił na powstanie nowej osady. Prawo powrotu nie dotyczyło jednak ludności arabskiej, która zostali wygnana ze społeczności bądź uciekła z Izraela w wyniku tej samej wojny ${ }^{35}$.

\footnotetext{
30 Ibidem.

31 Cytat za: ibidem, s. 241.

32 J. Jarząbek, Palestyńczycy na drodze..., s. 225-227.

33 P. Codogni, Protesty w Bilin. Kreatywna walka bez przemocy, „Sprawy Międzynarodowe” 2018, nr 4, s. 270-271.

34 Diakonia International Humanitarian Law Centre, History of Israeli Settlement Policy, https:// www.diakonia.se/en/IHL/where-we-work/Occupied-Palestinian-Territory/Administrationof-Occupation/Israeli-Settlements-policy/History/ (3 V 2021).

35 Peace Now, Gush Etzion...
} 
Jest to dowodem na to, iż z początkiem okupacji Zachodniego Brzegu interesy arabskich cywilów były dla władz Izraela podrzędne względem osadników żydowskich. Kfat Etzion należy do większego bloku osadniczego Gush Etzion, który jest de facto kompleksem kolonii. Zagęszczenie obszaru pomiędzy Jerozolimą (a dokładnie Betlejem) a Hebronem sprawia, iż przyczółki tworzą dosyć zwarty rejon przy granicy $\mathrm{z}$ tzw. Zieloną Linią. $Z$ biegiem czasu terytorium rozwijało się i tym samym stawało się bardziej zwarte, a idea większego bloku osadniczego rozszerzała się o kolejne projekty. Przykładem jest włączenie ortodoksyjnej dzielnicy żydowskiej Bejtar Illit oraz kolonii Efrata. Ta druga jest położona $\mathrm{z}$ dala od Zielonej Linii i leży po wschodniej stronie głównej drogi biegnącej z północy na południe Zachodniego Brzegu Jordanu (Route 60) ${ }^{36}$. Rozwój bloku osadniczego oraz włączenie osady biegnącej wzdłuż głównej drogi stwarza sytuację, w której Gush Etzion jest bardzo gęstym, ścisłym i zbitym obszarem funkcjonującym na Terytoriach Okupowanych. Ponadto, w kontekście tego rozszerzonego bloku osadniczego istotny jest fakt istnienia bariery bezpieczeństwa, którego trasa formalnie określa granice Gush Etzion. Włączenie w ten rejon osady Efrata oznacza również, że główny odcinek trasy Route 60 leży po izraelskiej stronie muru bezpieczeństwa ${ }^{37}$. Kompleks osad w 2004 r. liczył 12 kolonii, z czego 8 zostało utworzonych niezgodnie $\mathrm{z}$ izraelskim prawodawstwem ${ }^{38}$. Według dubajskiego dziennika „Khaleej Times” w roku 2011 liczba przyczółków wynosiła 22, a mieszkało w nich ok. 70 tys. osadników ${ }^{39}$. Pokazuje to, że osadnictwo żydowskie na Zachodnim Brzegu Jordanu wciąż rośnie, a kwestie prawa międzynarodowego i izraelskiego są sprawą drugorzędną. Polityka izraelska wobec Zachodniego Brzegu zakłada tworzenie gęstych sieci osad i rozwój bądź otaczanie przez przyczółki najistotniejszych z punktu widzenia władz państwa punktów na mapie, w tym m.in. Wschodniej Jerozolimy. Pomimo statusu i kwestii legalności osiedli widać, iż zakładanie przyczółków nieprzerwanie odbywa się za pomocą taktyki faktów dokonanych przy bierności instytucji państwowych.

Niejasny status nieautoryzowanych kolonii sprawia, że wiele $\mathrm{z}$ nich, w tym Kfar Etzion, funkcjonuje jako enklawy Izraela. Z reguły mają one dostęp do edukacji, służby zdrowia, a także funkcjonują w nich jednostki bezpieczeństwa ${ }^{40}$. Kfar Etzion również nie jest wyjątkiem w tej kwestii. Pomimo iż nie ma tam szkoły podstawowej, to mieszkańcy mają dostęp do edukacji w pobliskich miejscowościach. W osadzie znajduje się otwarta dwa razy w tygodniu klinika,

36 Ibidem.

37 Ibidem.

38 Ibidem.

39 Khaleej Times, West Bank settlers shrug of Obama call, https://www.khaleejtimes.com/region/ west-bank-settlers-shrug-off-obama-call (3 V 2021).

40 Walla News, Neighborhood Procedure: Between the town of Beit Omer and the settlement of Kfar Etzion (tłumaczone z języka hebrajskiego), https://news.walla.co.il/item/2540816 (3 V 2021). 
jedna centralna synagoga oraz sklep odzieżowy ${ }^{41}$. Mieszkańcy przyczółka płacą również podatki, m.in. od nieruchomości. Warto dodać, że w przypadku braku dostępu do którejś ze sfery życia społecznego, osady wzajemnie się wspierają oraz udostępniają swoje placówki mieszkańcom z sąsiednich kolonii. Tak jest np. z edukacją oraz służbą zdrowia ${ }^{42}$. Osady tworzą zatem zwarty blok miejscowości, które wzajemnie się wspierają i uzupełniają w ramach potrzeb, jednak najbardziej widoczną kwestią jest sfera polityczna. Osady w systemie bezpieczeństwa Izraela mają otaczać ważne ośrodki i punkty na mapie, czego przykładem jest blok osadniczy Gush Etzion wraz z osadą Kfar Etzion otaczający Wschodnią Jerozolimę.

W działaniach władz izraelskich można zaobserwować aprobatę dla zasiedlania Wschodniej Jerozolimy przez osadników żydowskich. Oprócz wspomnianego przykładu Kfar Etzion oraz kompleksu Gush Etzion, gdzie podane przypadki dotyczą terytoriów poza Jerozolimą, warto zauważyć, że rośnie liczba osadników przenoszących się do palestyńskich dzielnic na Starym Mieście wewnątrz Wschodniej Jerozolimy. Dzielnice te to: Silwan, Abu Dis, Ras al-Amud, a-Tur oraz Sheikh Jarrah, w których można się doliczyć setek osadników ${ }^{43}$. W celu zasiedlania wyżej wymienionych dzielnic, władze izraelskie usuwają palestyńskie rodziny $\mathrm{z}$ ich posiadłości, przekazując je w ręce nowych mieszkańców. Rodzi to bardzo duże komplikacje, co przeradza się w napiętą sytuację społeczną. To z kolei prowadzi to starć pomiędzy osadnikami, a młodymi Palestyńczykami. Problemem w tym aspekcie są także kwestie ekonomiczne. Proces wysiedlania ludności arabskiej zmusza ją do prowadzenia długich oraz kosztownych procesów sądowych dotyczących zgodności przesiedleń w świetle prawa izraelskiego ${ }^{44}$. Według danych przedstawianych przez B’Tselem z problemem przesiedleń $\mathrm{w}$ dzielnicach jerozolimskich zmaga się ponad 150 rodzin $^{45}$.

W kontekście kwestii palestyńskiej prawo Państwa Izrael jest rzeczą mało klarowną. Przepisy funkcjonujące $\mathrm{w}$ państwie istnieją w próżni i są stosowane tylko w wybranych sytuacjach bądź wobec danej grupy społecznej, wyznaniowej czy etnicznej. Tak jest m.in. z prawem powrotu, które miało zastosowanie w czasie zakładania kolonii Kfar Etzion po wojnie sześciodniowej, lecz nie mające zastosowania względem cywilów arabskich. Na ten sam przepis powołują się różne organy reprezentujące osadników żydowskich. Izraelskie prawo umożliwia Żydom roszczenia do własności posiadanych przez nich bądź przez innych Żydów przed

41 Ibidem.

42 Ibidem.

43 B'Tselem (The Israeli Information Center for Human Rights in The Occupied Territories), East Jerusalem cleansing continues: Israel removes more Palestinian families, hands over their homes to settlers, https://www.btselem.org/jerusalem/20190311_east_jerusalem_cleansing_ continues (3 V 2021).

44 Ibidem.

45 Ibidem. 
rokiem 1948. To samo prawo nie dotyczy jednak ludności arabskiej. Co więcej, zabrania ono Palestyńczykom analogicznego ubiegania się o majątek, który posiadali przed $1948 \mathrm{r}^{46}$. Podobną sytuację przedstawiał przykład Kfar Etzion, co ilustruje politykę władz państwa żydowskiego wobec osadnictwa. Wszelkie próby podejmowane przez Arabów celem dochodzenia swoich praw własności zakończyły się fiaskiem. Apele oraz odwoływanie się do izraelskich sądów wszelkiej instancji także zakończyły się niepowodzeniem. Działania podejmowane względem ludności arabskiej zamieszkałej w Jerozolimie skrajnie różnią się od postępowania władz wobec osadnictwa żydowskiego i całego procesu kolonizacji, co wpisuje się w szerszą politykę wewnętrzną państwa w wymiarze społecznym, politycznym oraz tożsamościowym. Można wywnioskować, że prawo izraelskie w tym kontekście jest stosowane na podstawie wyznaczników pochodzeniowych i narodowościowych, wobec czego Żydzi mają uprzywilejowaną pozycję względem nieżydowskich członków społeczeństwa kraju.

Jedną z dzielnic jerozolimskich, która wpisuje się w wyżej opisaną politykę władz izraelskich wobec ludności arabskiej w Izraelu jest Sheikh Jarrah. 15 II 2021 r. 6 rodzin $z$ tego dystryktu otrzymało werdykt w apelacji przeciwko zamiarze eksmisji z czterech domów. Wywłaszczenia przeprowadzane są na rzecz osadników żydowskich. Izraelski sąd nakazał rodzinom opuszczenie swojego miejsca zamieszkania w ciągu 2 i pół miesiąca, do $2 \mathrm{~V} 2021$ r. $^{47}$. Pokój Teraz wskazuje, że wysiedlenia ludności palestyńskiej to szerszy element polityki władz państwa żydowskiego w polityce wewnętrznej kraju. Organizacja podaje, że

Ta sytuacja nie jest prawna, ale polityczna. Sąd jest jedynie narzędziem, za pomocą którego osadnicy przy ścisłej pomocy władz państwowych dokonują przestępstwa wysiedlenia całej społeczności i zastąpienia jej osadą (żydowską - P.K.). Rząd izraelski i osadnicy nie mają problemu z wysiedleniem tysięcy Palestyńczyków w imię „prawa powrotu” do posiadłości przed 1948 r., podczas gdy stanowczo twierdzą, że miliony Izraelczyków mieszkających w palestyńskich posiadłościach przed 1948 r. nie mogą zostać eksmitowani (.... ${ }^{48}$.

Pokój Teraz również wskazuje na dyskryminację Palestyńczyków na płaszczyźnie prawnej. Według izraelskiego prawodawstwa Żydzi, którzy utracili swoje posiadłości we Wschodniej Jerozolimie w wyniku wojny o niepodległość (1948) mogą otrzymać je z powrotem w posiadanie nawet kosztem wywłaszczeń palestyńskiej ludności. Natomiast w stosunku do Palestyńczyków stosuje się prawo o mieniu nieobecnych (ustawa o własności nieobecnych), które zakłada, że jeżeli

46 Ibidem.

47 Peace Now, The District Court Rejected the Appeal of 6 Families from Sheikh Jarrah, https:// peacenow.org.il/en/\%D9\%8Dsheikh-jarrah-appeal-rejected-160221 (3 V 2021).

48 Cytat za: ibidem. 
właściciel nieruchomości opuścił swój dom przed 1 IX 1948 r. niezależnie od tego czy jest uchodźcą palestyńskim ${ }^{49}$, czy wrócił do swojej posiadłości po chwilowej nieobecności bądź cały czas przebywał na terytorium Izraela nawet w pobliżu swojego domu, to jego posiadłość może ulec konfiskacie ${ }^{50}$. W Izraelu dochodzi zatem do kuriozalnej sytuacji, w której obywatele tego państwa podlegają innym przepisom w zależności od tego czy dana osoba jest Żydem, czy Arabem.

\section{Podsumowanie}

Wydarzenia w Sheikh Jarrah oraz związane z nimi napięcia wywołały wyraźny sprzeciw społeczności międzynarodowej, co przejawiło się w protestach m.in. w Australii, Stanach Zjednoczonych oraz Anglii, gdzie ludzie zebrali się tłumnie aby wyrazić poparcie dla Palestyńczyków. Wzrost antagonizmów między stronami doprowadził do eskalacji sporu. Interwencje izraelskich sił bezpieczeństwa przeniosły się na Wzgórze Świątynne, gdzie dochodziło do incydentów na tle religijnym. Starcia na linii Izrael i osadnicy przeciwko ludności palestyńskiej zintensyfikowały spór do wymiany ataków rakietowych pomiędzy Hamasem a Izraelem. Narastanie napięć do stopnia wymiany rakietowej nie napawa optymizmem i nie daje dobrych prognoz na przyszłość. Jest to dowód na nieprzejednaną postawę Izraela dla utrzymywania, finansowania i rozwoju osadnictwa żydowskiego wraz z wywłaszczaniem palestyńskiej ludności. Biorąc pod uwagę, iż osadnictwo żydowskie jest jednym z najbardziej newralgicznych elementów konfliktu izraelsko-palestyńskiego, obecna sytuacja zdecydowanie zmniejsza szansę nie tylko zażegnania sporu, ale również prowadzenia dialogu oraz rozmów pokojowych. Zdecydowana postawa władz państwa żydowskiego wobec kolonizacji Zachodniego Brzegu Jordanu mającej niepewny status prawny, zarówno w legislacji izraelskiej, jak i międzynarodowej, jest jedną z przyczyn, która oddala osiągnięcie porozumienia na linii Izrael - Palestyna.

49 W wyniku wojny z 1948 r. stworzono specjalną definicję uchodźcy palestyńskiego, która dokładnie określa kogo można uznać za uchodźcę palestyńskiego. Wg definicji jest to osoba, która co najmniej 2 lata przed ucieczką żyła w brytyjskim Mandacie Palestyny, a jej ucieczka wynikała $\mathrm{z}$ ratowania własnego życia i utraty swoich domów podczas I wojny izraelsko-arabskiej oraz potomstwo tych osób. Za: UNRWA, Palestine Refugees, https://www.unrwa.org/ palestine-refugees (3 V 2021).

50 Peace Now, The District Court Rejected... 


\section{Abstract}

\section{Piotr Kosiorek}

\section{Jewish settlements in the context of the Israeli - Palestinian conflict}

Jewish settlement is one of the most important elements of the long - term contradictions between Israel and Palestine. Moreover, the legal status of the outposts is problematical. The main objective of this text is analysis the significance of Jewish settlement in the context of the Israeli - Palestinian conflict and to try to answer the question how high in the hierarchy of the State of Israel priorities is the Jewish settlement. In a content of this article there such matters as security wall with its functions and consequences for Palestinians in the context of Jewish settlements, issue of an administration of the West Bank and the case study describes example of the Kfar Etzion and Sheikh Jarrah.

Keywords: Israel, Palestine, Israeli - Palestinian conflict, Jewish settlement, West Bank

\section{References}

BBC News, Israel and the Palestinians: Can the settlement issue be solved?, https:// www.bbc.com/news/world-middle-east-38458884.

BBC News, Israel 'funded illegal outposts', http://news.bbc.co.uk/2/hi/middle_ east/4328817.stm.

Beinin, J., The Demise of the Oslo Process, https://web.archive.org/web/20000816222849/http://www.merip.org/pins/pin1.html.

B'Tselem (The Israeli Information Center for Human Rights in The Occupied Territories), East Jerusalem cleansing continues: Israel removes more Palestinian families, hands over their homes to settlers, https://www.btselem.org/jerusalem/20190311_east_jerusalem_cleansing_continues.

B'Tselem (The Israeli Information Center for Human Rights in The Occupied Territories), Planning Policy in the West Bank, https://www.btselem.org/planning_and_building.

B'Tselem (The Israeli Information Center for Human Rights in The Occupied Territories), The Separation Barrier - Statistics, https://www.btselem.org/separation_barrier/statistics.

Codogni, P., Protesty w Bilin. Kreatywna walka bez przemocy, „Sprawy Międzynarodowe" 2018, nr 4. 
Diakonia International Humanitarian Law Centre, History of Israeli Settlement Policy, https://www.diakonia.se/en/IHL/where-we-work/Occupied-Palestinian-Territory/Administration-of-Occupation/Israeli-Settlements-policy/ History/.

Dyduch, J., Izraelskie wybory a konflikt z Palestyńczykami w latach 1992-2003, [in:] Izrael i Autonomia Palestyńska, G. Tokarz, B. Albin (eds.), Wrocław 2007. Jarząbek, J., Palestyńczycy na drodze do niepodległości. Rozwój, przemiany i kryzys ruchu narodowego, Warszawa 2012.

Jarząbek, J., Żydowskie osadnictwo na Zachodnim Brzegu Jordanu, „Wschodnioznawstwo" 2007.

Khaleej Times, West Bank settlers shrug of Obama call, https://www.khaleejtimes. com/region/west-bank-settlers-shrug-off-obama-call.

Kibuc, https://encyklopedia.pwn.pl/haslo/kibuc;3921998.html.

Krzan, B., Izraelski mur bezpieczeństwa w świetle opinii doradczej Międzynarodowego Trybunału Sprawiedliwości, [in:] Izrael i Autonomia Palestyńska, G. Tokarz, B. Albin (eds.), Wrocław 2007.

Nüsse, A., Muslim Palestine: The ideology of Hamas, Amsterdam 1998.

Peace Now, The District Court Rejected the Appeal of 6 Families from Sheikh Jarrah, https://peacenow.org.il/en/\%D9\%8Dsheikh-jarrah-appeal-rejected-160221.

Peace Now, Settlement watch, https://peacenow.org.il/en/category/settlementwatch.

Strużyński, M., Hamas wobec sporu palestyńsko-izraelskiego. Między procesem pokojowym a eskalacja konfliktu, „Historia i Polityka” 2013, nr 9.

Szydzisz, M., Polityka Zagraniczna Palestyny, [in:] Wprowadzenie do polityki zagranicznej muzułmańskich państw Bliskiego Wschodu i Afryki Pótnocnej, M. Woźniak-Bobińska, A.M. Solarz (eds.), Warszawa 2018.

Szydzisz, M., Religijne wymiary konfliktu izraelsko-palestyńskiego, „Wschodnioznastwo" 2012.

Szydzisz, M., Sekurytyzacja jako narzędzie polityki zagranicznej Izraela w świetle teorii regionalnych kompleksów bezpieczeństwa, Warszawa 2019.

UNRWA, Palestine Refugees, https://www.unrwa.org/palestine-refugees.

Walla News, Neighborhood Procedure: Between the town of Beit Omer and the settlement of Kfar Etzion (tłumaczone z języka hebrajskiego), https://news. walla.co.il/item/2540816.

Piotr Kosiorek - mgr bezpieczeństwa międzynarodowego, doktorant w Zakładzie Badań Wschodnich w Instytucie Studiów Międzynarodowych Uniwersytetu Wrocławskiego w ramach Kolegium Doktorskiego Nauk o Bezpieczeństwie.

ORCID: 0000-0003-1618-6607 